\title{
Carl Schmitt's Metapolitics
}

\author{
Matthias Lievens
}

\section{Introduction}

How to make sense of Carl Schmitt's political thinking? The tremendous amount of secondary literature that appeared in the last twenty years testifies to the fact that many scholars of political theory have considered his work worthy of study. But what is it in his concept of the political that is of such interest and how can it be related to or separated from his very problematic stances on concrete political issues?

My contention is that, in order to understand the stake of Schmitt's work, one should analyze his philosophical strategy and his understanding of what political philosophy fundamentally is. In this paper, I will try to bring out the sophistication of Schmitt's philosophical strategy, which is not a "polemic in favor of pólemos, of war

to the death against a real, blood-spilling enemy,"1 but a metapolitical struggle against depoliticizing types of spirit or ways of thinking and for the particular spiritual form that makes conflicts political in the first place. What is important, is that Schmitt does not take an Archimedean standpoint, from where he might judge different subjects' positions, but that he intervenes on the level of the spirit in order to make political conflict between different subjects possible in the first place.

However, Schmitt's philosophy is not only an intervention to safeguard the political. It also constitutes an attempt to articulate the political and politics, or to 'place' the political in a particular way. Being one of the first authors to have drawn this distinction between politics and the political, Schmitt aims at repoliticizing politics, i.e. return political thrust to the particular social sphere of the state. As I will 
try to show, the relation between these different moments of his metapolitical strategy is aporetic. Nevertheless, despite the problematic nature of Schmitt's attempt to fuse politics and the political, his approach unveils something of the essentially spectral nature of each politicization. Behind each enmity, it turns out, stands another enemy. In the last part of this paper, I will discuss what this pluralization of enmities means for the concept of the political.

My aim is to unravel Schmitt's thought and to try to develop a diagnosis of where Schmitt's train of thought goes wrong, an analysis of the kernel of truth it contains, and an attempt to find a way out, beyond the limits of his concept of the political. In order to do so, one has to read Schmitt benevolently. I do not follow some readers' argument of Schmitt, which states that he should be dismissed as a political thinker altogether, because of his problematic political stances. The paradox of their argument is that by misrecognizing his work because he is an enemy only confirms Schmitt's conception of enmity. It is simply not possible to consider Schmitt as the absolute enemy, whose writings are not worth studying, without already being intellectually defeated by him: he has understood the meaning of such gestures much better than those who actually make them. In a certain way, one has to be a kind of Schmittian in order to understand what it requires to fight against and move beyond Schmitt. By taking Schmitt and his ideas seriously, one does exactly what he required of a political enemy: one is both a firm opponent and a respectful adversary. I consider this to be the only possible way to deal with and move beyond Schmitt. The most paradoxical aspect of this is that by thinking with, against, and beyond Schmitt, I also rescue him as a political philosopher worth studying. Somehow, I rescue my enemy. This is the kind of dialectic that would have fascinated Schmitt and that he was after in some of his most perspicacious passages on the intricacies of the political. 
However, my objective is not to legitimize Schmitt's work as a totality. It is rather to contribute to a reading of this work which is "neither apologetic, nor dismissive, but reconstructive and selective." ${ }^{\prime 2}$ It is to unravel his thought in order to show what it can contribute to a better understanding of what political action and thinking are about and to move beyond Schmitt's own depoliticizations.

\section{Fighting for the Political}

In the secondary literature, different hypotheses have been formulated to explain Schmitt's motivation to fight processes of depoliticization and the idea of a world without politics. While Leo Strauss argued Schmitt's case is based on a moral stance, Heinrich Meier thought it is rather undergirded by a theological conviction. ${ }^{3}$ Others have stressed that Schmitt's philosophy is based on myth, or on a bellicose and vitalistic Lebensphilosophie. ${ }^{4}$ All of these approaches tend to reduce Schmitt's argument for the political to an expression of underlying, non-political motives. They often have to put forward questionable assumptions for which very little textual evidence can be found in Schmitt's work. My hypothesis is that it does not make sense to try to firmly ground Schmitt's understanding of the political in ethical, theological, or even anthropological visions. Schmitt himself never explicitly constructs his concept of the political on the basis of such non-political starting points. He does not ask the question of the ultimate foundations of politics. This question would be depoliticizing par excellence: it would make it impossible to think the distinction between the sphere of politics and the political, and the contingent nature of the political, about which I discuss in greater depth below. ${ }^{5}$ 
Rather than looking for firm grounds, Schmitt starts in the middle. ${ }^{6} \mathrm{He}$ does not provide any substantial and foundational argument of why there is and should be politics in the world. In The Concept of the Political, for example, he states about the possibility of a world without politics: "If and when this condition will appear, I do not know." What Schmitt does know, however, is that a world without politics, like any type of world, cannot be realized without struggle. And a struggle for a world without politics would be the most intense and cruel form of struggle imaginable: "Between the universal end goal and the reality of the contemporary situation, another war would take place, possibly another 'final war of humanity,' in any case, a deeper and sharper, 'more total' war." ${ }^{, 8}$ The problem resides not just with the objective of a world without politics as such, but with the impossibility of developing a political strategy that effectively leads to the goal. ${ }^{9}$

Indeed, according to Schmitt, a struggle that aims at suppressing each enmity is no longer political. Such a struggle will render the enemy invisible, or symbolize him in specific, non-political ways. Fundamentally, it cannot but lead to the annihilation of the enemy as a political subject. It depoliticizes the enemy: it strips her of her political status and dignity and turns her into a criminal or inhuman being. According to Schmitt, understanding conflict in such a non-political way makes it unmanageable and interminable. A war of annihilation is a war that knows no limits. His basic argument for the political is thus fairly simple: when one does not acknowledge the existence of conflict and when one fails to recognize one's enemy as a political subject, one only makes conflicts worse. One does not create a world without politics in this way, but one engages in a politics of a degenerate kind, in policing rather than political action. 
Schmitt observes that in today's world there are conflicts, friend/enemy groupings, and decisions being made. The problem is that, as a result of the dominance of liberal, cosmopolitan, or economic-technical thinking, these conflicts tend to become invisible and are no longer understood as specifically political conflicts or decisions. Schmitt's political philosophy has to be understood as an intervention in a plural world whose plurality is threatened by these depoliticizing 'types of spirit.'

Throughout his oeuvre, Schmitt pays particular attention to the way friend/enemy oppositions are articulated through concepts and words. According to him, all political concepts are to be understood polemically, i.e. in terms of who is affected by them: "Every political concept is a polemical concept. It has an eye on a political enemy and its historical meaning is determined through its enemy. Words like sovereignty, freedom, rule of law, and democracy acquire their meaning through a concrete antithesis. ${ }^{10}$ Crucially, however, not all political concepts are polemical in the same way. Some conceal their polemical character, and this has particular effects on the spirit that governs people's self-understanding.

Time and again, Schmitt refers to the enigmatic concept of the spirit, which refers to the order of meaning that is the condition of possibility for human, and especially political, action. In today's philosophical jargon, it would be called the symbolic order. It is both constituted through polemics and struggle and, at the same time, produces the particular identities of the parties involved. What is crucial for understanding Schmitt's political philosophy, is that it is on the spiritual level that the political or non-political nature of a conflict is determined. My contention is that Schmitt's argument for the political should be understood as an argument for a particular type of spirit that makes it possible for the world to be understood as 
composed of a plurality of political friends and enemies. Depoliticizing types of spirit induce such a kind of self-understanding in actors as to make it impossible for them to enter into genuinely political relations with their 'other.' Therefore, Schmitt's argument for the political is based on a kind of critique of ideology, which tackles discourses that attempt to conceal their polemical nature or effects. It is an argument for safeguarding this plurality and its symbolization, which are, according to Schmitt's diagnosis of his time, increasingly threatened.

Schmitt consistently argues against ways of thinking that dehumanize the other and put her on another plane than the self, for example by using concepts like that of humanity. ${ }^{11}$ Such a concept does not allow for "differentiation," i.e. it makes it impossible for the world to be interpreted in terms of a pluriverse of political friends and enemies. ${ }^{12}$ It rather constructs the other as an inhuman subject which can legitimately be destroyed. What is crucial for enmity to be political, according to Schmitt, is that the conflict and its parties involved are made visible and present, and that a basic form of reciprocal recognition takes place between friend and enemy as political and human actors rather than as criminals or moral enemies. ${ }^{13}$ In "reciprocal recognition of recognition" resides the "greatness of the concept" of political enmity, according to Schmitt. ${ }^{14}$ Genuine political thought and action is "ad alterum," oriented to giving a legitimate place to the other. ${ }^{15}$

Humanitarian discourse is not capable of doing that. It generates a selfunderstanding which dehumanizes the enemy in advance and regards her as an immoral or criminal rather than as a political subject. ${ }^{16}$ This intensifies the relation between friend and enemy to such an extent as to push it "beyond the political."17 Schmitt locates the political on a scale of increasing intensity, ranging from a prepolitical level, on which the relation between human beings is not interpreted in terms 
of friend/enemy oppositions, via an actual political level, to what I would call a 'hyperpolitical' level situated on a plane "beyond the political," characterized by the moralization ${ }^{18}$ or theologization ${ }^{19}$ of the enemy. In this last case, enmity becomes absolute, and the conflict which it engenders, turns into an endless fight for the annihilation of the enemy. Only when enmity is relativized through reciprocal recognition, can it be genuinely political. ${ }^{20}$ The political is about finding a middle ground: it is about intense conflict, but this conflict should be made visible as political conflict and the actors involved should be treated as legitimate political subjects and human beings, rather than as (im)moral or criminal subjects.

It is important to add that symbolization does not only have effects on the other, the enemy, but also on the self. This is what Schmitt is aiming at when he repeatedly states that "the enemy is our own question as Gestalt" and that the enemy always "stands on my own plane." ${ }^{21}$ The enemy is not only the subject in confrontation with whom we forge our own identity, it is also the figure who questions our own political subjectivity, more precisely, who questions the way we constitute our subjectivity through the way we understand ourselves and symbolize our intersubjective relation with the other (the enemy). Our enemy questions our own self-understanding and appeals to us to become political. The question the enemy puts to us is about whether we are genuinely political, i.e. whether we recognize that we are involved in the intersubjective space of a political friend/enemy relation. As Schmitt states: “One classifies oneself through one's enemy. One ranks oneself through what one recognizes as enmity."22 One cannot deny the enemy’s political dignity without undermining one's own political subjectivity. If one depoliticizes the other, the enemy, one depoliticizes the self. The symbolic order through which the enemy is constructed somehow also grasps the self, and produces one's own 
subjectivity. In a sense, the self is always already grasped by an other that it cannot symbolically suppress without suppressing its own political subjectivity and dignity.

For Schmitt, the political is something important, something worth fighting for. And that is basically what he does throughout his many writings on the subject. Although they are always also interventions in concrete political matters, Schmitt's main books of the twenties, but also some of his later works, are philosophically located on a metalevel. They are not in the first place direct attacks against concrete political enemies, but polemic interventions on the level of the 'spirit' or the symbolic order. Schmitt's metapolitical strategy is a strategy to make sure that struggle is possible, that it is made visible and remains political.

Leo Strauss had already underlined that Schmitt's struggle for the political and against liberal depoliticizations has a special place within his overall strategy. According to Strauss, it was only "a concomitant or preparatory action," which had to clear the field for the confrontation with Schmitt's veritable enemy, "the spirit of technicity." ${ }^{23}$ Strauss rightly saw that there are different levels on which Schmitt wages his struggles. But he assumes that Schmitt's concept of the political is only a (preparatory) moment in the struggle against his true enemy. Before the struggle with this enemy can begin, the enemy that stands in its way has to be eliminated. However, Strauss did not see that Schmitt systematically operates in this way in many of his writings, and he consequently did not try to uncover the meaning of this operation. It seems that, rather than being a subordinate moment which has to make the struggle with his concrete enemy possible, this 'preparatory' struggle for 'the political' is a vital lead throughout Schmitt's oeuvre.

It is because of this metadimension that Schmitt's texts on the political are of such great interest for political philosophers. This is even more so because, as already 
stated, it is the essence of political thinking, according to Schmitt, to be polemical and divisive. When Schmitt fights for a public spirit that acknowledges conflict and division, he actually argues for a spirit that remains truthful to the essence of what political philosophy is, or, in other words, he gives political philosophy a crucial role in safeguarding its own principle and making it present and visible in the public sphere.

In a certain sense, therefore, Schmitt's metapolitical struggle is also a metaphilosophical struggle: it is a philosophy on what philosophy is or should be, and it is a struggle for the recognition of what its fundamental principle is. This metaphilosophy is divisive: it crucially distinguishes between (philosophical) friends and enemies. It fights against philosophical perspectives that fail to acknowledge their own polemic or divisive character, and which thus misrecognise the political, or, in one word, depoliticize. For Schmitt, all philosophy is divisive, but not all philosophy is divisive in the same way. In a certain way, Schmitt's notion of political enmity is an (inevitably polemical) meta-criterion that good (political) philosophy has to abide by and with which he tries to attack other philosophies. In this sense, it is a criterion to decide between philosophical enemies and friends, not in terms of immediate party interests, but in terms of the question whether they acknowledge conflict and contribute to making it political.

Schmitt's philosophical strategy thus consists of the attempt to find a way of thinking or 'spirit' that is genuinely political, taking place through polemics with depoliticizing and 'hyperpoliticizing' ways of thinking. This metapolitical thrust reappears in several guises throughout his work. In the 1929 lecture on 'The Era of Neutralizations and Depoliticizations,' for example, he does not attack technology as such, but technicity, the spirit of technical thinking which neutralizes the political. 
Technology is not the problem, it is the underlying type of Geist that is troubling Schmitt. A similar critique of technical and economic thinking as not being able to think political form is central in his book Roman Catholicism and Political Form. In The Crisis of Parliamentary Democracy, which in German has the more significant title Die Geistesgeschichtliche Lage des Heutigen Parlamentarismus, it is the "intellectual circumstances" of parliament that are at stake for Schmitt. ${ }^{24}$ What he is up to there is to unveil the underlying principles of the parliamentary institution and to show the extent to which these are or are not political.

In Political Theology, too, it is a specific 'type of spirit' which is his central object, namely a theological way of thinking. He is not in the first place interested in this because he wants to firmly ground his politics in theology (that would amount to a retheologization of politics, which he dismisses), but because he wants to mobilize a particular theological type of conceptualization in order to fight against depoliticizing ways of thinking in legal studies, such as rationalism and positivism. Within the framework of these last currents of thought, it is impossible to think the event of the decision, as everything is always already integrated in the causal relations of pure immanence. Theology provides a conceptual model that Schmitt tries to mobilize in his metapolitical struggle against such ways of thinking that make political decisions invisible.

According to Schmitt, the enemy or the political relation of enmity should be clearly identifiable and present. However, this presence and visibility were increasingly threatened, especially after the early modern state order of the Jus Publicum Europaeum broke down. From that moment on, different kinds of conflict arose that were not articulated in political, but rather in abstract, moral or historical- 
philosophical terms. As a result, the opponents disappeared as visible, political enemies. Only ghostly shades remained.

In several passages, therefore, Schmitt states that enmity increasingly tends to become spectral. It is concealed behind seemingly unpolitical discourses, although it does not therefore vanish as such. On the contrary, enmity becomes the spectre which haunts these discourses and makes them unpredictable and elusive. Schmitt considers this a very dangerous tendency. According to him, polemical concepts "turn into empty and ghostlike abstractions" when they are no longer "focused on a specific conflict" and are no longer "bound to a concrete situation." 25 Schmitt generally describes the struggle concealed behind such general and abstract concepts as spectral. Conflict then degenerates into a "spectral struggle of slogans and ideologies. ${ }^{26}$ In a sense, all discourses which ground a hyperpolitics are haunted. They conceal enmity, but at the same time intensify it and take it "beyond the political" through the act of concealment itself. Spectrality is Schmitt's way to think the continuing but furtive presence of the enemy in the effects of depoliticizing discourse. He strongly dismisses it in favor of the full presence, visibility, and univocal identity of the relation of enmity. In order to make that possible, he argues for a clear 'placing' of the political opposition.

\section{Placing the Political}

According to Schmitt, the political, as a specific symbolic configuration, could not only get lost as a consequence of depoliticizing discourses. It could also shift, deterritorialize, and pop up at any place within the social whole. ${ }^{27}$ In order to understand what is at stake, Schmitt operates a genuine conceptual revolution, by 
distinguishing between 'politics,' a specifically institutionalized social sphere, and the political, a particular way of symbolizing a social relation. This distinction is most clearly expressed in the first sentence of The Concept of the Political: "The concept of the state presupposes the concept of the political." 28 The friend/enemy criterion is basically an attempt to rethink 'the political' once it has clearly appeared that one cannot exclusively define it in terms of the state, the particular domain of 'politics.'

The rise of new conflicts outside the state sphere constituted the historical condition for Schmitt's distinction between politics and the political. As he states:

The classical profile of the state was shattered as its monopoly on politics waned. New...political protagonists asserted themselves... From this followed a new degree of reflection for theoretical thought. Now one could distinguish 'politics' from 'political.' The new protagonists become the core of the entire complex of problems called 'political.' Here lies the beginning and thrust of every attempt to recognize the many new subjects of the political, which become active in political reality, in the politics of the state or non-state, and which bring about new kinds of friend-enemy groupings. ${ }^{29}$

For Schmitt, the manifestation of the political outside of the state was a tremendous problem which puzzled him throughout his life. ${ }^{30}$ The shift or deterritorialization of the political basically follows two tracks. On the one hand, the political shifts along geographical space. Formerly non-politicized relations between territorial entities can become politicized (e.g. the constitution of new states in the 'south'). On the other hand, the political shifts within the social topology: from the state to society (or to particular social domains, such as the economy, culture, religion etc.). The most important manifestations of this movement of deterritorialization of 
the political that Schmitt discusses are class struggle and partisanship. ${ }^{31}$ One of the issues that bothered Schmitt, was that the shift of the political threatened to undermine the capacity of the state to create a normal situation, in which law could prevail. Both domestic law and international law required a clearly visible, univocal subject of political decision as their basis. In the twentieth century, however, the state was being undermined: "The state as the model of political unity, the state as the bearer of the most astonishing monopoly, namely the monopoly on the political decision, this high point of European form and western rationalism, is being dethroned." 32 Schmitt drew the distinction between politics and the political both in order to better understand his predicament, and to clarify the task he saw: to restore the monopoly of the political decision within the particular sphere of politics, and to reconfigure this sphere, the state (later the Reich), in such a way as to make that possible.

Indeed, although Schmitt urges for an understanding of the world as a pluriverse, against cosmopolitan projections of world unity, he remains very wary of ever new political subjects popping up and shifting friend/enemy lines. That is why he adds a second dimension to his metapolitical fight. His fight to give the political a place should be understood quite literally: it is about giving the political a place, in other words, to territorialize it, to prevent it from cropping up at unforeseen and dangerous places. He is not prepared to let the political logic of heterogeneity and differentiation fully develop its effects. In a text from 1932, Schmitt explicitly explains how he wants to deal with the fact of political pluralism. He does not aim at "the denial of the fact of this pluralism," but tries to realize a "correct placing of pluralism."33

Schmitt especially strives for a clear distinction between who can and who cannot constitute herself into a political subject, for a clearly identifiable distribution 
of politicizations and depoliticizations within the social whole. In this regard, he admires the early modern Eurocentric order of national states, the Jus Publicum Europaeum, because it realized such a distribution by 'placing' the political along clearly visible, in casu territorial lines: the sovereign state was the only legitimate political subject. The only political relation was the relation between sovereign states. Domestically, the rule of the police prevailed. ${ }^{34}$ Schmitt's fascination for and fear of the partisan becomes intelligible in this context. With the appearance of the partisan, a radically new type of enemy pops up that decenters the existing distribution of politicizations and depoliticizations. Schmitt calls partisanship an example of 'real' enmity, in order to distinguish it from 'conventional' enmity between states. The arrival of the partisan constitutes a genuine event that shakes the distribution of who is a visible and identifiable political subject and who is not. ${ }^{35}$ The partisan is a figure who disrupts the existing distribution of politicizations and depoliticizations, of political and non-political subjects. He undermines the univocity of political friend/enemy groupings, and introduces his own, new type of friend/enemy grouping. In this way, much to Schmitt's dislike, the number of political subjects multiplies. ${ }^{36}$

His focus on the 'placing' of the political adds a dimension to Schmitt's conception of political struggle. Such a struggle is not only a struggle against a concrete enemy and a (metapolitical) struggle to keep this conflict political. It is also a struggle to fix the friend/enemy groupings in particular 'places,' or to make sure such groupings only manifest themselves in particular places, and not elsewhere. In other words, it is a struggle to avoid that other types of friend/enemy groupings disrupt the political demarcation lines constituting the existing distribution of politicizations and depoliticizations. 
Evidently, there is a deep tension between these different levels: between the struggle for the political and the struggle for the correct placing of the political, between the deterritorialization of the political and its reterritorialization, between the political and politics. How can Schmitt avoid processes of politicization where he does not like them? How can he depoliticize social relations once they are actually politicized? How can he do this without engaging in active depoliticization, stripping particular actors of their political subjectivity and dignity? This is Schmitt's Achilles' heel.

My hypothesis is that the problematic character of a number of Schmitt's concrete positions (such as his advocacy of the strong state and a plebiscitary presidency, his authoritarian understanding of democracy, and his siding with the Nazis) follows from the way he intervenes in the increasing gap between politics and the political. One could suggest that this tension between politics and the political is inevitable and that the establishment of a particular distribution of politicizations and depoliticizations is inescapable if one wants to pacify society and create a normal situation in which law can prevail. But in the tension between politics and the political, many strategic options remain open. ${ }^{37}$ Schmitt's option is situated at one extreme of the spectrum: it is to give an exclusive monopoly of the political decision to the sphere of politics (the state). In the end, rather than being a defender of the political as such, Schmitt turns out to advocate the strict coincidence of politics and the political, or even the total subordination of the political to the domain of politics (and thus its fixation within the prevailing distribution of politicizations and depoliticizations). This cannot but have paradoxically depoliticizing effects on this domain. 
Crucial aspects of his thought bear witness to this vacillation between the political and politics: on the one hand, he locates constituent power with the people, as a force from below, on the other hand, he aims to present the state executive (in the case of Weimar Germany, the president) as the holder of the sovereign power to decide on the state of exception and thus as functioning as a kind of gatekeeper (the "guardian of the constitution") who can decide whether a popular movement is to be considered as an expression of the people's constituent power or whether it is just a "peril, a danger to the existence of the state." 38 On the one hand, he seems to acknowledge the people as a real political force, while on the other hand, he restricts genuine political initiative to the leader, which the masses can only acclaim, assuming them to be homogenous and harmonious. On the one hand, he acknowledges that everything can become political, on the other, he argues for a "total state" whose logic is that it condenses the political in one point. "Only a strong state can depoliticize," Schmitt states, but in order for it to be able to monopolize the political decision, the state cannot but turn into a police officer rather than a political agent. The staunchest defender of the political thus turns out to be an advocate of a series of strong depoliticizations and of police measures against potentially new political subjects.

As a result, the purity of the political Schmitt is after gets lost. Schmitt wants an order that makes clear distinctions between combatants and non-combatants and between peace and war. In this way, he aimed at making political antagonisms present and visible. But if every politicization is based upon particular depoliticizations, every visible political antagonism renders other possible antagonisms invisible. That is why the political is deeply spectral. ${ }^{39}$ Behind each enemy, there seems to stand another, probably not yet fully visible one. 


\section{In Search of a Third}

Schmitt constructed his notion of the political in terms of a strong duality between friend and enemy. But as each political struggle appears to contain different (metapolitical) struggles, it turns out that the number of enmities inevitably multiplies. First, there is the direct conflict itself. Second, there is the struggle against those who deny the conflict and conceal it through depoliticizing ways of thinking. This is a struggle on a metalevel for the political and against depoliticization. And third, there is the struggle for a particular 'placing' of political pluralism. This is the struggle against those who want to place the fault line between friend and enemy differently, and who advocate another vision on which subjects are decisively political. In a certain sense, the kind of metastruggles Schmitt wages are present in each political struggle, which, as a consequence, must be a multidimensional event. As a result, from the very beginning, the political could not be considered as 'pure' as Schmitt wanted. There were always already different types of enemy, or meta-enemies involved. There is always a "plurivocity" of enmities, pace Schmitt. In order to gain a more sophisticated (post-Schmittian?) understanding of what the political is about, it is necessary to move beyond the strict duality of friend and enemy and to try to account for this multiplicity of (at least potentially) political subjects. How to think about politics when there is more than such a duality?

Schmitt's work contains several clues for moving beyond this duality, even though this duality remains crucial. Within his perspective, one subject cannot be political. In solitude, there is no politics. It is only when two subjects meet as enemies that a specifically political logic unfolds. Even the sovereign is not alone in Schmitt. He only acts when there is an 'other' triggering his decision, even though Schmitt 
tends to depoliticize this 'other' moment by calling it the 'exception,' obfuscating the moment of conflict or struggle inherent to it. However, an understanding of the political cannot stop with the analysis of the two. From the very beginning, there are more subjects involved. They are subtly present in Schmitt's metapolitical struggles. Although Schmitt wages these metastruggles himself, he does not theorize what their implications are for the concept of the political and of political order. Still, we find in his work a few clues for analyzing a third position that is situated beyond this duality.

Different kinds of third actors pop up in his texts. Each has a particular effect on the process of politicization and on the possibility of political order. To a certain extent, they are useful for conceptualizing the position of the (meta-)enemies Schmitt confronts in his struggle for the political. There are three such 'thirds.' First, there is the higher third, who is a figure of depoliticization par excellence and whom Schmitt combats in his struggle for the political on the level of the spirit. Second, there is the neutral third, who makes it possible for the conflict to remain clearly placed and contained in a dual space of enmity. And third, there is the real third (the real enemy), who questions this 'placing' of the political and tries to introduce new fault lines. I will shortly discuss these three 'third figures,' and their implications for the concept of the political.

First, the 'higher third.' Schmitt vehemently rejects this figure as a moment in political order. The notion of the higher third refers to the instance that paradoxically contends to be politically neutral, although it at the same time pronounces a (moral) judgment and on this basis intervenes in the conflict. Humanitarian wars are a case in point. Fundamentally, Schmitt's struggle against depoliticization is a struggle against this logic of the higher third. ${ }^{40}$ According to him, there can be no politicization if this logic has its way. Against it, Schmitt states that conflicts 
can neither be decided by a previously determined general norm nor by the judgment of a disinterested and therefore neutral third party. Only the actual participants can correctly recognize, understand, and judge the concrete situation and settle the extreme case of conflict. ${ }^{41}$

Second, there is the neutral third. Schmitt discusses the neutral third in particular in his studies concerning international legal order. ${ }^{42}$ Within the framework of the Jus Publicum Europaeum, for example, the possibility for third parties to remain neutral in a conflict between two states made it possible for this conflict to be contained. The third parties did "not take sides but (kept) the stage of war separate from its audience, they (precluded) war from spreading beyond the specific friend/enemy platform." ${ }^{43}$ In the twentieth century, this source of containment of war increasingly fell apart. It became more and more difficult to remain neutral when conflict lines deterritorialized and when war was justified in moral terms. From the moment "the representation of a possible neutrality and therefore of an uninvolved 'third state' is denied," a "universal claim to domination" can be raised and unleash a logic of "just war" that undermines the dynamic of reciprocal recognition that is so crucial for the political as Schmitt understood it. ${ }^{44}$ For neutrality to be possible, it is essential that the fault lines of conflict and its protagonists be more or less stable and clearly placed. The intervention of a new, real enemy can blur these lines, and force the formerly neutral actors to take a stance.

This 'real enemy' is the third and most intriguing 'third' figure in Schmitt's work, most emphatically embodied in the partisan. Its 'real' character consists in the fact that it is to be distinguished from 'conventional' political subjects that are constituted by the prevailing distribution of politicizations and depoliticizations and 
its concomitant symbolic and institutional frameworks. In other words, the real enemy is a new, formerly unacknowledged political subject that arises in places within the social whole that were formerly considered to be non-political. The real enemy decenters the existing distribution of politicizations and depoliticizations.

Seen from the perspective of Schmitt's scale of intensity, real enmity appears as a borderline figure, situated on the verge between relative and absolute enmity. It can easily turn into absolute enmity, as it deliberately misrecognizes and withdraws from a number of institutional, territorial, or symbolic devices that facilitated reciprocal recognition and thus contained conventional conflicts. But this is not necessarily so, as Schmitt also recognizes that under certain conditions, the partisan can relativize enmity and thus remain genuinely political. This is for example the case when the partisan is recognized by a regular, conventional political subject with a specific interest in its struggle, or when her struggle remains purely defensive or telluric. "The partisan has then a real, but not an absolute enemy. That proceeds from his political character."45

This real, 'third' enemy does not only question the existing distribution of politicizations and depoliticizations, which, as I explained, attributes political status exclusively to conventional subjects. It also challenges Schmitt's concept of the political itself. It disrupts the clear-cut duality of friend and enemy, and adds a third figure. Schmitt is puzzled by the question whether it is possible at all to have two enemies at the same time. If, as he suggests, one's own identity is defined in relation to an enemy, having a multiplicity of enemies must result in a broken identity. From Schmitt's perspective, it seems that there can be only one enemy, or at least one type of enemy. Being confronted with more than one enemy was the fate of the French general Salan, who had founded the Organisation de l'Armée Secrète during the 
Algerian war of independence, thus going against his own government: "When Salan declared civil war, he was really making two declarations of enmity: continuation of regular and irregular war against the Algerian front, and inauguration of an illegal and irregular civil war against the French government." ${ }^{, 46}$ This fundamentally puts Schmitt's concept of the political into question:

Every two-front war poses the question of who the real enemy is. Is it not a sign of inner division to have more than one single real enemy? The enemy is our own question as Gestalt. If we have determined our own Gestalt unambiguously, where does this double enemy come from $?^{47}$

When a third inimical subject appears and attacks both sides in an existing conflict, the original friend/enemy duality is disrupted, and, as a consequence, the identity and self-understanding of the political subjects involved are shattered. ${ }^{48}$ The appearance of real enmity does not only generate a new dynamic of war that is not as easily containable. It also disrupts the originally univocal political opposition and installs several, heterogeneous relations of enmity.

Still, Schmitt suggests that the partisan reintroduces an 'either-or' logic through his decision on the real enemy: "Decisionist exactness governs the functioning of every modern organization, in particular every regular modern state army. So the central question for the situation of a contemporary general poses itself precisely in terms of an absolute either-or." ${ }^{, 49}$ When one decides on the real enemy, one does this in terms of an either-or, irrespective of conventional enmity. In this sense, a new duality is created, which no longer takes conventional oppositions into account. However, once the door is opened for non-conventional political subjects, ever new ones can crop up. The either-or would then again be disrupted. 
In a certain way, this happens every time a social group constitutes itself into a new political subject and makes its appearance on the field where conventionally recognized political actors face each other. Each real enmity multiplies political identities and subverts conventional forms of self-understanding. Once the logic of real enmity is unleashed, it does not seem to be easy to stop this multiplying and confusing logic of ever new 'real enemies' appearing on the scene. There is always the real possibility of an 'other enemy' disrupting the logic of Schmitt's dualistic understanding of the political. The two poles of a political antagonism are always haunted by a third. Schmitt has great difficulty dealing with this third. He elaborately discusses the problem of the other, the enemy, but seems to try to exclude this 'other enemy' from his theory of the state and the international order. Through his 'placing' of the political, Schmitt wants to create a political configuration of visible, discrete and non-overlapping political entities, but he ultimately turns out to be incapable of safeguarding the purity of the lines between these discrete entities and of exorcizing his specters.

The exclusion of this other or third enemy makes the ad alterum which is at the core of Schmitt's concept of the political very ambiguous. Friend and enemy recognize each other around their common fault line, but at the same time they ward off the 'other enemy,' this furtive third undermining the univocity of their enmity. In this sense as well, a decision for politicization might always contain a decision to depoliticize, to cut off a third's path to becoming a political subject, by virtue of the common solidarity of the two enemies reciprocally recognizing each other. Might not real recognition be recognition of the fact that there might be an 'other enemy,' beyond the actually existing fault line? Might not genuine political action and thought be concerned with the 'real possibility' of other, third political subjects, rather than 
with the 'real possibility' of a fight with a clearly visible and already present political subject? Is the real ad alterum not the respect for the not yet visible enemy? But if one takes spectrality into account and lets one's image of the enemy be questioned by an 'other enemy,' can one then still have an intense political relation with the first enemy? It seems that the appearance of an 'other enemy' cannot but have profound consequences for the political nature of the first relation of enmity. The concealment of the 'other enemy' seems to be the hidden presupposition of every dual friend/enemy configuration. It is the precondition for the full visibility of the political friend/enemy duality itself. There seems to be an inevitable moment of 'rendering invisible' behind each process of visible politicization.

\section{Specters of the Political}

If it is true that each enmity is haunted by a plurality of enmities, one should turn Schmitt's depiction of modern history on its head. According to Schmitt, the Jus Publicum Europaeum somehow provided the purest manifestation of the political, as it created the conditions for relative enmity. Therefore, the Jus Publicum Europaeum embodied the truth of the political in his eyes. ${ }^{50}$ However, Schmitt's positive depiction of this early modern order and his attempts to reproduce it in a certain way, obfuscate its spectres. If one wants to recreate a strong order of the Jus Publicum Europaeum-type under contemporary circumstances, one cannot but repressively depoliticize the non-conventional enemy. This 'other enemy' is potentially political in a more direct sense than the conventional enemy. Conventional enmity "could be conceived as a game," Schmitt states. ${ }^{51}$ In a game, all players and rules are fixed in advance. The partisan, in contrast, "restored the seriousness of war." In partisan conflict, political subjectivity can shift and rules are unstable. If rules exist at all, they 
arise through the conflict itself. In real enmity, the political potentially discards its juridical or official shell, and can appear in its naked reality.

Therefore, it seems as if the truth of the political did not disclose itself in the Jus Publicum Europaeum, but rather in the era which followed it, and in which the hidden political precondition of the Jus Publicum Europaeum became visible. Schmitt hesitantly acknowledges this in his text on partisanship. Finally, he gives the exception a political name: the real enemy. The appearance of the partisan represents the return of a repressed truth, namely the truth of the fact that the political cannot be reduced to politics, and that its shifting, deterritorializing, and contingent thrust cannot be kept within the bounds of a univocal confrontation between stabilized enemies. It turns out to be impossible to circumvent the plurivocity of the political and to reduce the political to the univocal and game-like face-to-face opposition of conventional enemies.

As a result, it seems we remain saddled with the real enemy, representing forms of politicization that cannot so easily be territorialized. Perhaps the strong conception of order Schmitt prefers has become impossible in a deeply politicized society? If that is the case, one will have to find other ways to deal with real enmity.

From a (post-)Schmittian perspective, any discussion on the possibility of political order in a post-national era must start from the existence of real enmity. By creating new sources and places of politicization, real enmity by definition disrupts the existing distribution of politicizations and depoliticizations. How can it then not result in chaos? Which clues can one find in Schmitt to make sure real enmity does not turn into absolute enmity? Can the confrontation between real enemies obtain a minimum of regularity? How can the political configuration that results from the dynamic of real enmity contribute to keeping this enmity political, i.e. to making it a 
form of relative rather than absolute enmity? That was Schmitt's puzzle: "The question...is whether the enmity can be contained and regulated, that is, whether it represents relative or absolute enmity." ${ }^{, 2}$

Schmitt does not have a lot to say about this. In general, the distinction between relative and absolute enmity and that between real and conventional enmity remains undertheorized in his work. Apart from his general stress on the spirit or symbolic order, and its role in keeping off absolute enmity, two elements could be developed in order to understand how real enmity can remain relative. The first is the partisan's (and thus the real enemy's) dependence on and orientation to regularity. Even though the political is increasingly emancipated from the state, it still needs the state or a similar kind of institutional order as a presupposition of this very emancipation. The existence of an order characterized by the territorialization of the political (i.e. the attempted fixation of the political to particular points in the social whole) is the condition of possibility for its deterritorialization. Speaking about real enmity does not make sense if there are no conventional enemies from which real enmity can be distinguished. The constitution of new, extraordinary political subjects presupposes the existence of conventional, normal political subjects. As Schmitt stresses, "in the longer view of things the irregular must legitimize itself through the regular, and for this only two possibilities stand open: recognition by an existing regular, or establishment of a new regularity by its own force." 53

What does it mean for a real enemy to try to establish a new regularity? I would suggest that what is at stake for her, is to gain recognition as a political force to be taken into account. In other words, she strives for a different distribution of politicizations and depoliticizations. To paraphrase Jacques Rancière, she strives for a new "counting of the parts": "Political struggle is not a conflict between well defined 
interest groups; it is an opposition of logics that count the parties and parts of the community in different ways." 54 Similarly, real enmity in Schmitt introduces a new 'counting' of the political subjects at play and results in a new distribution of who is a political subject and who is not. Understanding that such a recount provides a political answer to real enmity implies that one should remain open to a multiplication of political subjects. Schmitt certainly would have abhorred that, because he saw how the newly arising conflicts of his time, such as class conflict, tended to present themselves as 'the last war of humanity,' thus becoming a form of absolute enmity and making their orientation to a 'new regularity' very dubious.

However, there is one other element that Schmitt has not developed, and that can provide part of an answer to this: the fact that the pluralization of political subjects as such might contribute to a certain containment of conflicts. It is striking that both the concept of absolute enmity and that of conventional enmity are based on a similar condition, namely a univocal understanding of the friend/enemy duality. In a certain way, both deny the existence of a third enemy: conventional political subjects do this because the very appearance of such a third would undermine their monopoly on the political decision, while absolute enmity does not allow for anything beyond an annihilating either-or. Of course, conventional enmity was relativized and contained because of the presence of neutral thirds, which is not the case with absolute enmity. Still, both are thought of in terms of a univocal duality between enemies. My contention is that Schmitt tends to downplay how the multiplication and plurivocity of enmities can contribute to containing conflict. Indeed, what this multiplication does, I would suggest, is to render it ever more difficult to reduce enmity to one alldetermining duality or to symbolically render it in the form of such a duality. The specter of the 'other enemy' prevents the political from assuming the form of an 
absolute totality. It is no longer possible to construct one's opposition to an other as an absolute opposition when one has to position oneself along other conflicting lines as well. As Ernesto Laclau suggests, when real enmities are multiplied, absolute enmity becomes a construction that "will always be essentially incomplete." 55 The line dividing the absolute friend from the enemy will then be crossed over, questioned and relativized by heterogeneous oppositions.

That is how it became ever more difficult to reproduce the univocal dualism of absolute class enmity, for example. The mythical image of an increasingly intense class polarization that Marx and Engels set out in The Communist Manifesto has been questioned both in the name of the internal political differentiation of the classes themselves, and by the appearance of irreducibly different struggles, such as those of feminism and of oppressed national or cultural minorities. The logic of real enmity that class struggle first unleashed and that was subsequently pursued by other political subjects as well paradoxically contributed to the relativization of class struggle itself. It multiplied the lines of enmity beyond the univocity of either conventional or absolute enmity. Ever new real enmities appeared that questioned the distribution of politicizations and depoliticizations a certain type of Marxism had defended in the past. In a certain way, class conflict is one of the oppositions that have been most haunted by their 'other enemies.'

Schmitt did not envisage this possibility, but continued to advocate a strong conception of order, in which the political would remain a univocal relationship between well-defined, conventional subjects. He did not dare take the risk of engaging with the slippery field of multiple real enmities. His focus remained on the political subject and her intersubjective relation with the singular other, and he did not elaborate on the effects of the multiplication of political enmities on enmity as such. 
Afraid of uncontrollable processes of ever new policitizations and of their decentering effect on political identities, he opted for a single source of politicization over a plurality of politicizations counterbalancing each other.

Unsurprisingly, the forms of containment of partisan conflict that he analyzed were mostly based on the subjective decisions of the partisan himself, rather than on the objective structure of the political configuration. For him, both the interconnectedness with regularity and, related to that, respect of territorial boundaries are to a certain extent the object of political decisions by political actors. They are matters of subjective choice. Schmitt states for example that "whether the enmity can be contained and regulated, that is, whether it represents relative or absolute enmity...(the) warring party alone must decide this on its own account." ${ }^{, 56}$ Schmitt provides only a few clues for addressing the question of how the structure of a political situation might push or force a political subject to contain her conflict with the other. He might have learned more from Clausewitz in this regard. Panajotis Kondylis has shown that, from a Clausewitzian perspective, the objective structure of political intercourse creates a kind of friction that can result in a certain containment of conflict. ${ }^{57}$ We might hypothesize that the multiplication of enmities has a similar effect. Unfortunately, Schmitt did not elaborate on this. ${ }^{58}$

This analysis of the multiplication of enmities has consequences for thinking about the political. For Schmitt, being political means that one lets oneself be put into question by one's enemy. But it must be more than that: it can also mean one is put into question by a not yet visible enemy, an 'other enemy,' by ever new enemies. The questioning of oneself thus remains open on principle. This entails a decisive profanation and relativization of any struggle, which can no longer be thought of as an absolute, one-to-one confrontation between friend and enemy ('class against class'). 
There is always a third, and even many thirds, who are not just neutral bystanders, but potential political subjects in themselves able to question this political demarcation

line.

\footnotetext{
${ }^{1}$ Sarah Pourciau, "Bodily Negation: Carl Schmitt on the Meaning of Meaning," MLN, No. 120 (2006), 1067.

${ }^{2}$ Andreas Kalyvas, "Review Essay: Who's Afraid of Carl Schmitt," Philosophy \& Social Criticism 25, No. 5 (1999), 89.

${ }^{3}$ E.g. Leo Strauss, "Notes on the Concept of the Political," in The Concept of the Political ed. George Schwab (Chicago: University of Chicago Press, 1996); Heinrich Meier, Carl Schmitt and Leo Strauss: The Hidden Dialogue (Chicago: The University of Chicago Press, 1995), 30.
}

${ }^{4}$ Richard Wolin, "Carl Schmitt, Political Existentialism, and the Total State," Theory and Society, 19, No. 4 (1990). 399; Jürgen Habermas, The Inclusion of the Other. Studies in Political Theory (Cambridge: Polity Press, 1998), 134; Mark Neocleous, "Friend or Enemy? Reading Schmitt Politically," Radical Philosophy 79 (1996), 18; John McCormick, Carl Schmitt's Critique of Liberalism. Against Politics as Technology (Cambridge: Cambridge University Press, 1999), 10. For a trenchant critique, see Kalyvas, "Review Essay: Who's Afraid of Carl Schmitt?"

The interpretation of Schmitt as an advocate of struggle for the sake of struggle overlooks how Schmitt explicitly distances himself from the kind of agonism that is advocated by Ernst Junger for example.

Cf. Carl Schmitt, "Politik," in Staat, Grossraum, Nomos. Arbeiten aus den Jahren 1916-1969 (Berlin: Duncker \& Humblot, 1995), 137; see also Wolfgang Palaver, Die Mythische Quellen des Politischen. Carl Schmitts Freund-Feind-Theorie (Stuttgart: Kohlhammer, 1998), 23; Wilfried Nippel, "Krieg als Erscheinungsform der Feindschaft," in Der Begriff des Politischen. Ein Kooperativer Kommentar ed. Reinhard Mehring (Berlin: Akademie Verlag, 2003), 66; Theo De Wit, De Onontkoombaarheid van de Politiek. De Soevereine Vijand in de Politieke Filosofie van Carl Schmitt (Ubergen: Pomppers, 1992), 436.

${ }^{5}$ Schmitt thus prefigures what is now called the 'post-foundational' approach in political philosophy. Cf. Oliver Marchart, Post-Foundational Political Thought: Political Difference in Nancy, Lefort, Badiou and Laclau (Edinburgh: Edinburgh University Press, 2007).

${ }^{6}$ According to Carlo Galli, "political existence is actually being thrown in the world and in history (Geworfenheit - meaning 'to be thrown')." Carlo Galli, "Carl Schmitt's Antiliberalism: its Theoretical and Historical Sources and its Philosophical and Political Meaning," in Cardozo Law Review 21, No. 5-6 (2000), 1605.

${ }^{7}$ Carl Schmitt, The Concept of the Political (Chicago: University of Chicago Press, 1996), 53-54.

${ }^{8}$ Carl Schmitt, Die Wendung zum Diskriminierenden Kriegsbegriff (Berlin: Duncker \& Humblot, 1988), 50.

${ }^{9}$ Another example of this non-foundational and metapolitical strategy of Schmitt is provided by his discussion of the concept of the exception, about which he states in Political Theology: "Whether one has confidence and hope that it can be eliminated depends on philosophical, especially on philosophical-historical or metaphysical, convictions" (Carl Schmitt, Political Theology. Four Chapters on the Concept of Sovereignty (Cambridge: MIT Press, 1988), 7). However, although Schmitt clearly argues for a way of thinking that acknowledges the exception, he does not develop any 'philosophical-historical or metaphysical' theory to show the inevitability of the exception. Instead, he limits himself to showing the effects particular discourses have on the exception: legal-political orders constructed on the basis of a mode of thinking that does not acknowledge the exception and the sovereign decision will be unable to decide when an exceptional situation occurs, or they will have to rely on "apocryphal acts of sovereignty," which problematically lack the public and open character of real sovereign decisions (E.g. Carl Schmitt, Verfassungslehre (Berlin: Duncker \& Humblot, 1993), xiv).

${ }^{10}$ Carl Schmitt, Hugo Preuss. Sein Staatsbegriff und Seine Stellung in der Deutschen Staatslehre (Tübingen: Verlag von J.C.B. Mohr, 1930), 5 (my translation).

${ }^{11}$ Other examples Schmitt provides of discourses that make enmity absolute are value philosophy, technical thinking, and certain philosophies of history. 
${ }^{12}$ Schmitt, The Concept of the Political, 54 .
${ }^{3}$ About the importance of reciprocal recognition between enemies for the political, see Matthias

Lievens, "Carl Schmitt's Two Concepts of Humanity," Philosophy and Social Criticism, 36 (8), 917934. One might be tempted to compare Schmitt's notion of recognition with Hegel's master-slave dialectic. However, while for Hegelians (like Kojève and Fukuyama) the desire for recognition becomes an essential aspect of human nature the fulfilment of which constitutes the end of history, for Schmitt recognition is not the objective of political struggle, but the condition of possibility for genuine political struggle. Recognition in Schmitt requires abstracting from a whole series of substantial (ethical, religious, economic, etc.) characteristics of the enemy, in order to relate to him in a purely political way.

${ }^{14}$ Carl Schmitt, Ex captivitate salus. Erfahrungen der Zeit 1945/47 (Berlin: Duncker \& Humblot, 2002), 89.

${ }^{15}$ Ibid. 13, 23; See also Carl Schmitt, Die Diktatur. Von den Anfängen des modernen Souveränitätsgedankens bis zum proletarischen Klassenkampf (Berlin: Duncker \& Humblot, 1994), xviii; Carl Schmitt, "Die Lage der Europäischen Rechtswissenschaft," in Verfassungsrechtliche Aufsätze aus den Jahren 1924-1954: Materialien zu einer Verfassungslehre (Berlin, Duncker \& Humblot, 1985), 422-423.

${ }^{16}$ Elsewhere, I have argued that there are two concepts of humanity in Schmitt's work, one that is polemically used to delegitimate an opponent, and another, 'regulative' concept of humanity, that cannot be appropriated by any particular political actor, but is present in the relation of reciprocal recognition between enemies as political and human subjects. Matthias Lievens, "Carl Schmitt's Two Concepts of Humanity," Philosophy and Social Criticism, 36 (8), 917-934.

${ }^{17}$ The English translation "transcending the limits of the political framework" (Schmitt, The Concept of the Political, 36) does not have the strong and concise meaning as the original German "über das Politische hinausgehend." Carl Schmitt, Der Begriff des Politischen: Text von 1932 mit einem Vorwort und drei Corollarien. (Berlin: Duncker \& Humblot, 1991), 37.

${ }^{18}$ Carl Schmitt, Glossarium. Aufzeichnungen der Jahre 1947-1951 (Berlin: Duncker \& Humblot, 1991), 190; The Concept of the Political. Chicago, 36; "The Theory of the Partisan. A Commentary/Remark on the Concept of the Political," in The New Centennial Review 4, no.3 (2004), 67.

${ }^{19}$ Schmitt, Ex Captivitate Salus, 89 ; “The Theory of the Partisan," 66 ; Glossarium, 190 ; Der Begriff des Politischen, 64 ; Politische Theologie II. Die Legende von der Erledigung jeder Politischen Theologie (Berlin: Duncker \& Humblot, 1996), 83 ; Carl Schmitt and Schickel, Joachim, Gespräche mit Carl Schmitt (Berlin: Merve Verlag, 1993), 86 ; Jacob Taubes, En Divergent Accord. A Propos de Carl Schmitt (Paris: Payot et Rivages, 2003), 25.

${ }^{20}$ Schmitt clearly distances his own political conception of enmity from the absolute notion of enmity: "Who is involved in a struggle with an absolute enemy... is not interested in our effort of finding a criterion for the political whatsoever. This rather appears to him as a threat for his direct combative force, a weakening as a consequence of reflection, a hamletization, and a relativization which is suspicious." Carl Schmitt, Het Begrip Politiek (Amsterdam: Boom, 2001), 134 (this note is not integrated in the 1996 English edition of The Concept of the Political).

${ }^{21}$ Schmitt, "The Theory of the Partisan," 61; Glossarium, 243. In Ex Captivitate Salus, Schmitt also states: "Miserable are the annihilators who justify themselves by saying that one should annihilate the annihilators. But all annihilation is mere self-annihilation." Ex Captivitate Salus, 90 (my translation).

${ }^{22}$ Ex Captivitate Salus, 90 (my translation).

${ }^{23}$ Leo Strauss, "Notes on the Concept of the Political," 118.

${ }^{24}$ Carl Schmitt, The Crisis of Parliamentary Democracy (Cambridge: MIT Press, 1992), 1.

${ }^{25}$ Schmitt, The Concept of the Political, 30.

${ }^{26}$ Carl Schmitt, "Völkerrechtliche Neutralität und Völkische Totalität," in Positionen und Begriffe: im Kampf mit Weimar, Genf, Versailles 1923-1939 (Berlin: Duncker \& Humblot, 1994), 295.

${ }^{27}$ Carl Schmitt, "Ethic of State and Pluralistic State," in The Challenge of Carl Schmitt, ed. Chantal Mouffe (London: Verso, 1999), 203 ; "Das Problem der innerpolitischen Neutralität des Staates," in Verfassungsrechtliche Aufsätze, 56.

${ }^{28}$ Schmitt, The Concept of the Political, 19.

${ }^{29}$ Quoted in Georges Schwab's introduction to Schmitt, The Concept of the Political, 12-13.

30 "With this phrase (that the concept of the state presupposes the concept of the political, ML), I can tell my whole juridical-constitutional life story." Carl Schmitt, "Von der TV-Demokratie. Die Aggressivität des Fortschritts," in Deutsches Allgemeines Sonntagsblatt 26 (1970). 


\footnotetext{
${ }^{31}$ Eckard Bolsinger, The Autonomy of the Political. Carl Schmitt's and Lenin's Political Realism (Westport: Greenwood Press, 2001), 36; Carl Schmitt, Politische Theologie II, 21.

${ }^{32}$ Schmitt, Het Begrip Politiek, 46-47.

${ }^{33}$ Schmitt, "Ethic of State and Pluralistic State," 204 (my emphasis).
}

Note that what is called 'de/reterritorialization' and 'placing' here, should not strictly be understood in terms of Schmitt's spatial theory of the nomos. The latter is only one instantiation of Schmitt's more general objective to fix a particular distribution of politicizations and depoliticizations that allows for the clear visibility and 'presence' of political demarcation lines.

${ }^{34}$ Carl Schmitt, "Die Ära der Integralen Politik,” in: Frieden oder Pazifismus? Arbeiten zum Völkerrecht und zur internationalen Politik 1924-1978 (Berlin: Duncker \& Humblot, 2005), 464. That Schmitt is after a clear determination of who can and who cannot be a political subject is made quite explicit in his post war work in which he critically discusses the notion of 'just war.' According to him, war for a 'just cause' tends to moralize and depoliticize the enemy. He advocated the notion of 'just enemy' as an alternative. This was one of the cornerstones of the Jus Publicum Europaeum: only sovereign states were just enemies, they had the right to decide on friend and enemy and to engage in conflict. Because their right to act politically was recognized, the conflict could be contained in the first place. This notion of just enemy has a counterpart, however: only particular subjects can be political. The just enemy is the intranomic enemy, who fights within the framework of a particular nomos. See Alberto Moreiras, “Against Cultural-Political Closure,” in: South Atlantic Quarterly 104, No. 2 (2005), 271.

${ }^{35}$ The arrival of the real enemy thus resembles very much Rancière's 'part of those who have no part' that disrupts the existing 'distribution of the sensible.' Jacques Rancière, Disagreement: Politics and Philosophy (Minneapolis: University of Minnesota Press, 1999).

${ }^{36}$ What Schmitt dislikes the most in generalized politicization, is not the fact that everything becomes the object of political decision as such. He is perfectly happy with a (total) state intervening in every social sphere. What disturbed him, is the multiplication of different types of political subjects, as a result of ever new events of politicization ("incompatible friend-enemy alternatives"). Carl Schmitt, "Weiterentwicklung des Totalen Staats in Deutschland," in: Positionen und Begriffe: im Kampf mit Weimar, Genf, Versailles 1923-1939 (Berlin: Duncker \& Humblot, 1994), 215.

${ }^{37}$ This kind of tensions is what made it possible for very divergent philosophical and political currents to have an interest in Schmitt, from radical leftists and emancipatory thinkers to counterrevolutionaries and conservatives, and to push his ideas into very divergent directions.

${ }^{38}$ Carl Schmitt, Political Theology, 6. See also, Carl Schmitt, Der Hüter der Verfassung (Berlin: Duncker \& Humblot, 1996). One of the aims of instituting a 'guardian of the constitution,' according to Schmitt, is to make the right to resistance by the people superfluous (p. 21). He thus attempts to deprive popular forces of a prerogative through which they can constitute themselves into political subjects.

39 The political must have been impure from the very start. That is what Derrida wanted to show in his deconstruction of Schmitt's concept of the political in Politics of Friendship: "there is the spectre, lodged within the political itself; the antithesis of the political dwells within, and politicizes, the political." Jacques Derrida, Politics of Friendship (London: Verso, 1997), 138.

${ }^{40}$ Already in Political Romanticism, he pointed to the logic of the "higher third" as representing a futile attempt to find "a way out of the either-or." Carl Schmitt, Political Romanticism (Cambridge: MIT Press, 1986), 117.

${ }^{41}$ Schmitt, The Concept of the Political, 27. One could consider Schmitt's vision of the state (and its executive branch in particular) in its relation to conflicts within society and as the guardian of the constitution as also following a logic of the higher third. Schmitt wants to reinforce the state in order for it to be capable of depoliticizing society again. In paragraph 3, I already shortly hinted at the aporetic nature of this endeavor, which Schmitt claims is aimed at enhancing the political status of the state, but ends up turning this state into a police apparatus.

${ }^{42}$ Carl Schmitt, "Das neue Vae Neutris!" (1938), in: Positionen und Begriffe im Kampf mit WeimarGenf-Versailles 1923-1939 (Berlin: Duncker \& Humblot, 1994), 286-290.

${ }^{43}$ Brett Levinson, "The Coming Nomos; or, The Decline of Other Orders in Schmitt," in The South Atlantic Quarterly 104, no. 2 (2005): 207-208.

${ }^{44}$ Carl Schmitt, Die Wendung zum diskriminierenden Kriegsbegriff (Berlin: Ducker \& Humblot, 1988), 41.

${ }^{45}$ Carl Schmitt, "The Theory of the Partisan," 65.

${ }^{46}$ Schmitt, "The Theory of the Partisan," 60.

${ }^{47}$ Ibid., 60-61. 


\footnotetext{
${ }^{48}$ Ernesto Laclau, “On 'Real' and 'Absolute' Enemies," in The New Centennial Review 4, no. 1 (2005): 5.

${ }^{49}$ Schmitt, "The Theory of the Partisan," 61-62.

50 "The classical concept of the political as fixed in the eighteenth- and nineteenth-century was founded on the state of European international law. This concept understood the war of classical international law as a pure state-war contained by international law. Since the twentieth century, however, this mode of state-war with its containments was set aside and replaced by the revolutionary partisan-war."

Schmitt, "The Theory of the Partisan," 34.

${ }^{51}$ Ibid., 63.

${ }^{52}$ Ibid, 42.

${ }^{53}$ Ibid, 53.

${ }_{54}^{54}$ Jacques Rancière, Aux Bords du Politique (Paris: Gallimard, 1998), 239.

${ }^{55}$ Laclau, "On 'Real' and 'Absolute' Enemies," 10.

${ }^{56}$ Schmitt, "The Theory of the Partisan," 42.

${ }^{57}$ Panajotis Kondylis, Theorie des Krieges. Clausewitz - Marx - Engels - Lenin (Stuttgart: KlettCotta, 1988), 145.

${ }^{58}$ Neither did he theorize what the fences or containments separating 'secondary politics' (within a political unity) from supposedly primary politics (between political unities) might consist of, and how they might let conflict unfold within particular domains of the social whole, keeping it there and not letting it overflow onto the whole social fabric. In general, he failed to think the particularity and situatedness of specific conflicts. Class conflict, religious conflict, and conflict around cultural issues may not all have the same dynamic, modalities or impact on the social whole. What Schmitt fails to see is that even if everything is political, not everything is political in the same way. He is badly equipped for understanding the qualitative differences between antagonisms and their differential insertion and containment within the social whole. It seems as if, despite his attempt to become more concrete in his book on the partisan, he is still not concrete or historical enough in his analyses of enmities.
}

\section{Matthias Lievens is}

